\title{
CURAR NA ARQUEOLOGIA: PRESERVAÇÃO DOS REMANESCENTES ÓSSEOS HUMANOS DO LARGO DA IGREJA NOSSO SENHOR DO BONFIM- TAPERAGUÁ, MARECHAL DEODORO, ALAGOAS
}

Paulo Cesar Bezerra Neri Junior ${ }^{i}$

Scott J. Allen ${ }^{\text {ii }}$

Resumo: Pesquisas arqueológicas no Largo da Igreja Nosso Senhor do Bonfim, no bairro de Taperaguá, em Marechal Deodoro, Alagoas, foram realizadas como atividade preliminar e concomitante às obras de requalificação do Largo. O resultado proveniente dessa pesquisa revelou vestígios ósseos humanos, e vestígios do cotidiano. Sabe-se o quanto é importante a limpeza do material arqueológico quando é retirado de campo, principalmente material ósseo humano, pois guardam potencialmente informações sobre sexo, ancestralidade, idade estimada, entre outros. Dessa forma esse texto tem como objetivo mostrar o processo de curadoria, e os procedimentos adotados para conservação do material ósseo humano encontrado no Largo. Realizou-se a limpeza mecânica a seco, assim como a limpeza com água deionizada. Os resultados foram satisfatórios, dos 6 indivíduos submetidos aos processos de curadoria 90\% tiveram sua integridade e morfologia óssea restaurada. Os 10\% resultaram para ossos com sua integridade restaurada, porém sua morfologia não. Palavras-Chaves: Curadoria; Limpeza; Esqueleto.

i Discente, Departamento de Arqueologia, Universidade Federal de Pernambuco-UFPE, paulo61_junior@hotmail.com

iiDocente, Departamento de Arqueologia, Universidade Federal de Pernambuco-UFPE, scott.allen@ufpe.br

\begin{abstract}
Archaeological research at the public square (Largo) of the Nossa Senhora do Bonfim Church, located in the Taperaguá, neighborhood of Marechal Deodoro, Alagoas, was carried out as preliminary to, and concomitant with civil works projects to reform the Largo. The project revealed several burials, as well as artifacts attesting to everyday life. It is known how important the cleaning of archaeological material is as soon as it is removed from the field, especially human bones, as they hold potentially information about sex, ancestry, age, among aspects. Thus, this text aims to illustrate the curation process and procedures adopted for the conservation of human bone material found on the Largo. Mechanical dry cleaning was performed as well as deionized water cleaning. The results were satisfactory: of the 6 individuals submitted to curation processes, some had $90 \%$ of their integrity and bone morphology restored. The remaining $10 \%$ had their integrity restored, but not morphology. Keywords: Curation; Cleaning; Skeleton.
\end{abstract}




\title{
Introdução
}

\begin{abstract}
Pesquisas arqueológicas no Largo da Igreja Nosso Senhor do Bonfim, no bairro de Taperaguá em Marechal Deodoro, Alagoas, foram realizadas como atividade preliminar e concomitante às obras de requalificação do Largo. $\mathrm{O}$ Termo de Referência, (TR), documento que estabelece os parâmetros de projetos preventivos, foi redigido originalmente pela Superintendência do IPHAN em Alagoas, e adotado pelo município de Marechal Deodoro. O TR estabelecia as condições de um estudo que permitia a realização das pesquisas arqueológicas por um período sem interferência do empreendimento, ou seja, sem a necessidade imediata de acompanhamento de obras (Allen, Porsani e Poluha 2017:236).
\end{abstract}

Em se sabendo o quanto e importante à limpeza do material arqueológico quando sai de campo, principalmente quando se trata de material ósseo humano, pois mostra informações do seu hábito de vida, dieta alimentar, sexo, ancestralidade, idade estimada, patologias, entre outros. "Por esta razão, a conservação e a restauração do material ósseo humano tornam-se importante ferramenta na reconstituição de aspectos culturais, na discussão da relação homem-natureza em todos os aspectos" (Bezerra e Silva, 2009:123). Assim, "garantir a restauração e a conservação desses espécimes poderá levar a um estudo mais detalhado e, consequentemente, mais próximo da realidade acerca da morfologia, da ecologia e das doenças que afetavam as populações pré-históricas ou históricas" (Op. Cit.).

Assim, deve-se registrar todos os procedimentos, desde a limpeza à análise do material com fotografias, relatórios e preenchimento de formulários. "Quando realizarem tratamentos de conservação em campo ou em laboratório, e imperativo registrar-se, de forma detalhada tudo o que foi feito ao objeto, inclusive para o armazenamento e para transporte devem ser acondicionados individualmente em recipientes rígidos e bem acolchoados" (Lorêdo, 1994:47).

Para esse trabalho foi proposta a retirada mecânica a seco ${ }^{1}$, assim como utilizando água deionizada ${ }^{2}$. Para ossos em estado de deterioração foi aplicada uma solução consolidante de PVA neutro mais água deionizada, que foi usada para reconstituir alguns ossos. "A limpeza de materiais esqueletais, juntamente com o restauro e acondicionamento, são essenciais no contexto de uma coleção, pois a preservação de informações importantíssimas depende da boa realização dessas etapas" (Okumura, 2015:217). Com essa colocação da pesquisadora, cabe refletir as formas que se pode trabalhar para a limpeza e análise do material ósseo,

\footnotetext{
${ }^{1}$ Limpeza com a utilização de ferramentas sensíveis para a retirada do sedimento sem o acompanhamento de água deionizada.

${ }^{2}$ Utilizada quando o sedimento está bem compactado sobre os ossos.
} 
diagnosticando o grau de fragilidade dos ossos, e quando alcançado os resultados, atribuir diferentes formas de limpeza. "Quando se encontra um material em situação mais delicada é necessário empregar alguns cuidados para manter o estado de conservação satisfatório" (Dias, 2013:104)

Esse texto tem como objetivo mostrar como foi realizado o processo de curadoria dos remanescentes ósseo humano, descoberto durante a pesquisa arqueológica no Largo da Igreja do Nosso Senhor do Bonfim, Taperaguá, Marechal Deodoro, Alagoas. Dessa forma, apresentam-se os objetivos de curadoria para os materiais ósseos, um breve contexto das escavações, a preservação do material, a metodologia proposta para a curadoria dos ossos, os resultados e uma sucinta conclusão.

\section{Curadoria}

Uma vez que se reconhece a relevância da preservação da cultura material, objeto de estudo da Arqueologia, como testemunho das sociedades que viveram muito antes do presente, se evidencia a necessidade de utilizar técnicas para manter estes materiais o mais próximo possível do estado físico original, bem como preservar as informações acerca de tais objetos. Assim, a preservação e a conservação se unem à arqueologia para juntas obterem conhecimentos que se perpetuarão (Op. Cit.).

Os procedimentos envolvidos no resgate de objetos e remanescentes biológicos recuperados em contexto arqueológico e as condições gerais dos mesmos in situ são fundamentais para determinar as necessidades curatoriais e as ações específicas relacionadas à conservação preventiva desses materiais, enquanto objetos pertencentes ao Patrimônio Cultural, integrantes de acervos e coleções institucionais (Carvalho, 2017:220).

Dessa forma as ações e processos de curadoria nos materiais arqueológicos são essenciais para uma longevidade e integridade futura, mostrando à sociedade os valores gerados, seja material ou imaterial das populações passadas.

Alguns pesquisadores têm narrado um panorama a respeito da definição de curadoria de uma forma mais ampla. Como mostra Lessa (2017:233), o conceito surgiu influenciado pela importância da análise de evidências materiais da natureza e da cultura, mas também, pela necessidade de tratá-las no que corresponde à manutenção de sua materialidade, à sua potencialidade enquanto suportes de informação e à exigência de estabelecer critérios de organização e salvaguarda. Refletindo sobre a indagação da pesquisadora, é de suma 
Curar na Arqueologia: Preservação dos Remanescentes Ósseos Humanos do Largo da Igreja Nosso Senhor do Bonfim-Taperaguá, Marechal Deodoro, Alagoas

importância o tratamento perante os materiais arqueológicos em campo e laboratório mantendo a sua integridade.

Para um bom trabalho e desenvolvimento em um processo de curadoria é necessário conhecimento especifico do material ao qual vai ser trabalhada, cerâmica, ossos, etc. e, quais referências serão usadas para comparações e desenvolvimento dos processos curatoriais, quais ferramentas serão usadas para melhor resultado nas aplicações das soluções consolidante, limpeza, coleta, entre outros.

Os procedimentos de salvaguarda, uma vez articulados com os saberes especializados demandados para a coleta, identificação e interpretação das coleções arqueológicas em geral e de remanescentes humanos especificamente, são fundamentais para o desenvolvimento de um programa sistemático de curadoria (Lessa, 2017:233).

Segundo Okumura: "A curadoria de restos esqueletais humanos é uma tarefa bastante complexa cuja especificidade exige do curador um conhecimento profundo não somente da coleção em questão, mas também de discussões de ordem ética e técnica" (Okumura, 2015:211). Principalmente, cabe ao pesquisador ter um conhecimento anatômico de ossos humanos, assim como experiência em escavações com sepultamentos no âmbito arqueológico.

Os formulários que são implementados para o processo de curadoria são essenciais para um controle das etapas de conservação dos materiais arqueológicos. Para Lessa (2017:234), a elaboração e aplicação de protocolos de curadoria que prevejam procedimentos a serem adotados, a partir do momento de evidenciação do material esquelético no sítio arqueológico são, sem dúvida, condições fundamentais para o estabelecimento de uma cadeia operatória mais controlada nas suas etapas de conservação e manutenção, e muito mais eficiente no objetivo de potencializá-lo enquanto fonte de informação. Lessa pontua: “[...] a elaboração dos protocolos de escavação e de procedimentos curatoriais realizados em campo será sempre ajustada tanto em função das especificidades do sítio quanto da instituição onde o material ficará depositado" (Op. Cit.).

Contudo, para esse trabalho o processo de curadoria foi de forma simples e criteriosa, respeitando os limites do material arqueológico e dos processos de curadoria, nesse caso ósseo, utilizando referências textuais e orientações de especialista no âmbito bioarqueológico como de conservação e restauro. Todas as etapas de curadoria foram registradas com relatórios e fotografias para um controle das informações geradas durante todo o trabalho. 


\section{Escavação Arqueológica no Largo da Igreja Nosso Senhor do Bonfim, Taperaguá, Marechal Deodoro, Alagoas}

O PAC-Cidades Históricas ${ }^{3}$ tem incentivado a realização de obras de requalificação de espaços públicos em muitas cidades brasileiras, ocasionando assim a aproximação de empresas de engenharia, arqueologia e instituições de pesquisa. Os serviços arqueológicos vão desde acompanhamento e monitoramento até o resgate de grandes espaços, mostrando, no caso de Marechal Deodoro, Alagoas, a revelação de diversos materiais atestando ao cotidiano, estruturas coloniais e enterramentos humanos.

Pesquisas arqueológicas foram realizadas como atividade preliminar e concomitante às obras de requalificação do Largo da Igreja Nosso Senhor do Bonfim, no bairro de Taperaguá, em Marechal Deodoro, Alagoas (Figura 1). O Termo de Referência, redigido originalmente pela Superintendência do Iphan, em Alagoas, e adotado pelo município de Marechal Deodoro, criava as condições para a realização de um estudo coerente com os objetivos de uma arqueologia científica e outra que objetiva o cumprimento das leis patrimoniais (Allen, 2017:3).

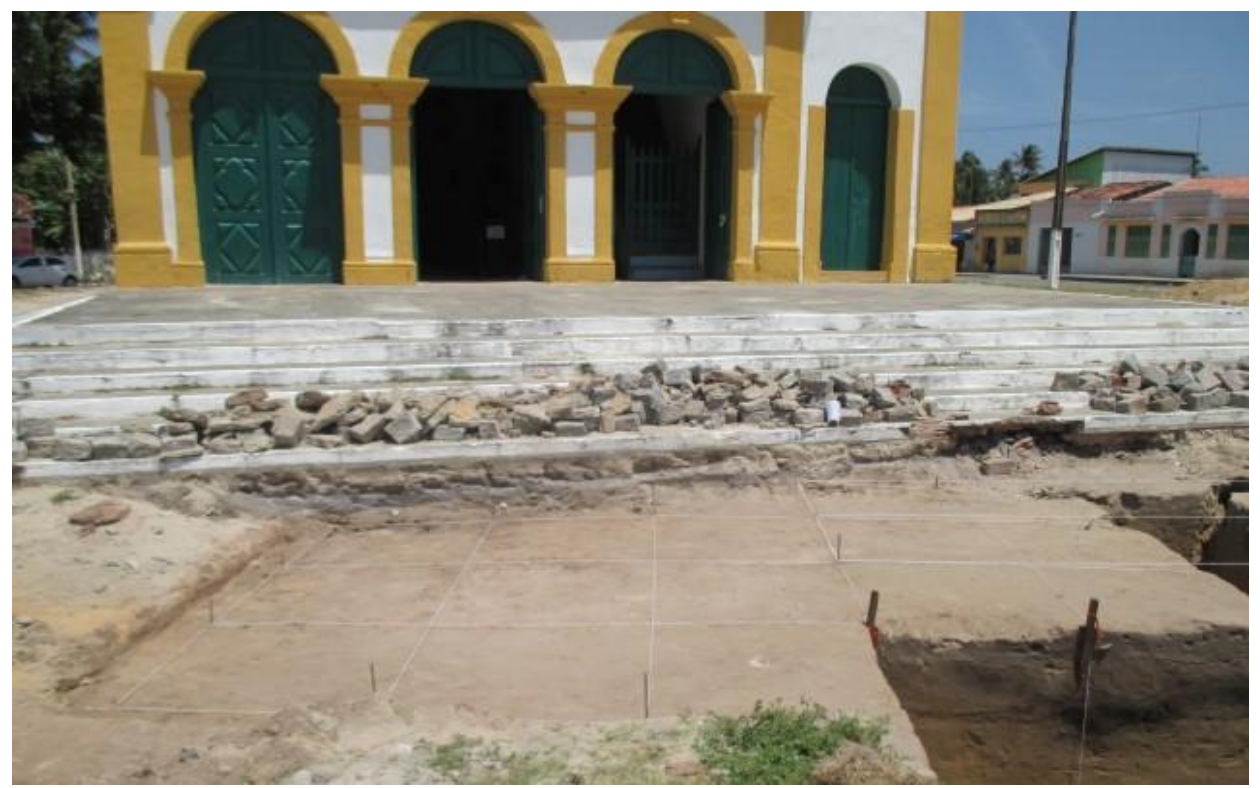

Figura 1: Escavações arqueológicas no largo da Igreja Nosso Senhor do Bonfim. Fonte: Acervo Nepa, 2017.

${ }^{3}$ Programa de Aceleração do Crescimento (PAC), iniciado em 2007, é uma inciativa do governo federal coordenada pelo Ministério do Planejamento que promoveu a retomada do planejamento e execução de grandes obras de infraestrutura social, urbana, logística e energética do Brasil. 
“O presente estudo procura, através da arqueologia, acrescentar conhecimento sobre as primeiras investidas coloniais em Marechal Deodoro em geral, e do Largo da Igreja Nosso Senhor do Bonfim, especificamente" (Op. Cit.). Acredita-se que o nascimento da atual cidade Marechal Deodoro teve seu início no atual bairro de Taperaguá, porém existem "imprecisões de datas sobre o florescimento da nucleação urbana, havendo inferências de sua existência em fins do século XVI [..]" (Ferrare, 2002 apud Allen, 2017:4). Taperaguá foi removido do centro da povoação, para o monte Cruciforme, onde está assentada a velha e nobilíssima cidade das Alagoas (Moraes, 1886 apud Allen, 2017:4) (Figura 2).

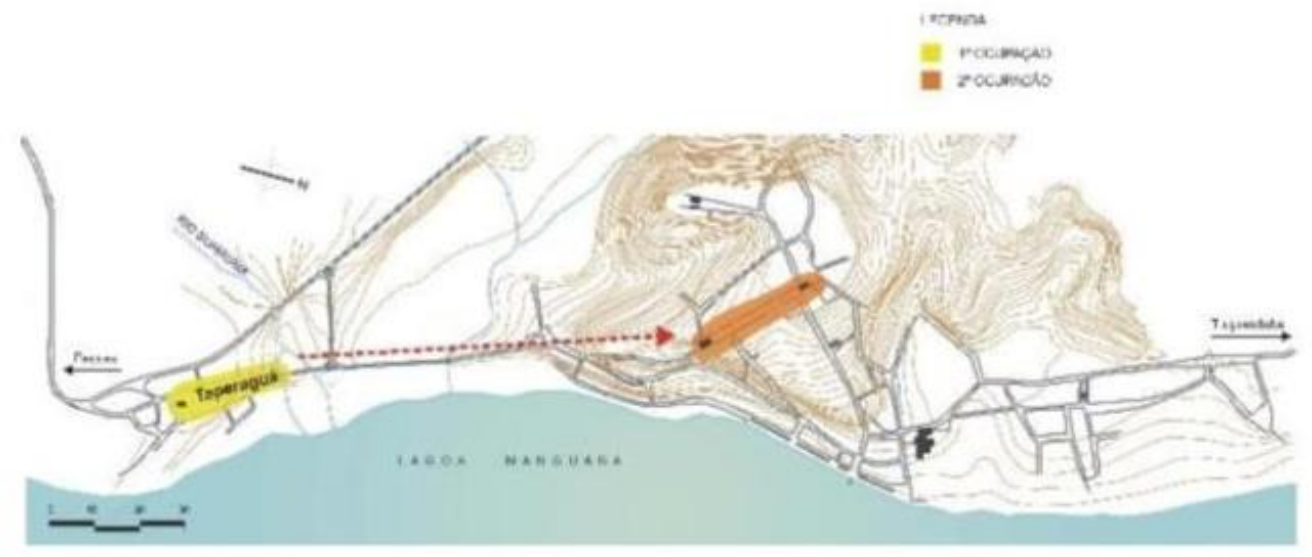

Figura 2: Mapa Altimétrico referente a primeira e segunda ocupação em Alagoas. Fonte: Ferrare, 2007 apud Allen, 2017.

Contudo Taperaguá remonta através das memorias históricas, desde os primórdios da ocupação de Alagoas. Dessa forma, o bairro de Taperaguá já aponta para algumas questões que podem ser abordadas pelos métodos de Arqueologia histórica. De interesse geral era a formação sociocultural, econômica e religiosa dessa 'povoação' inicial de Marechal Deodoro (Allen, 2017:5).

Dentre essas questões está a Igreja do Nosso Senhor do Bonfim, onde nas obras de requalificação do Largo, o acompanhamento arqueológico se fez presente, por se tratar de um patrimônio histórico, por compromisso em mostrar a história da cidade para a comunidade que hoje existe e que ainda usufrui do espaço sagrado.

O Largo foi e ainda é local usado para diversos fins, incluindo colocação de lixo dentro e fora de recipientes adequados, conserto de automóveis e caminhões, barracos de bar, circo itinerante, festas municipais e assim por diante. Essas atividades, comum para áreas urbanas, resultam na distribuição de uma diversidade de materiais arqueológicos [...] (Allen, 2017:6). 
As escavações arqueológicas no largo da Igreja Nosso Senhor do Bonfim trouxeram à tona diversos materiais arqueológicos como vidro, louça, metal e osso, com destaque a esse último material. Foram encontrados seis indivíduos humanos articulados, ao quais, alguns sepultamentos tiveram as marcas de covas identificadas (Figura 3 e 4). "Sem dúvida, as evidências materiais mais intrigantes se remetem à escavação de seis enterramentos". (Allen, 2017:132) (Figura 5 e 6).

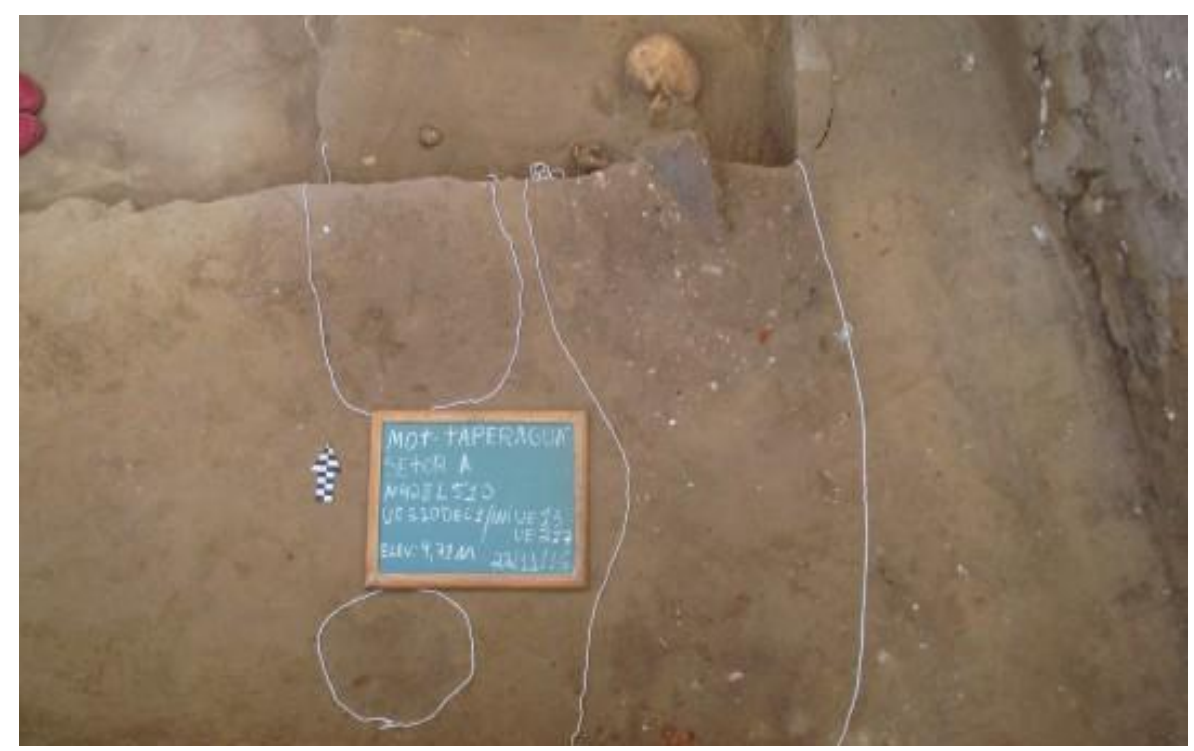

Figura 3: Sepultamento mostrando delimitação da cova. Fonte: Allen, 2017.

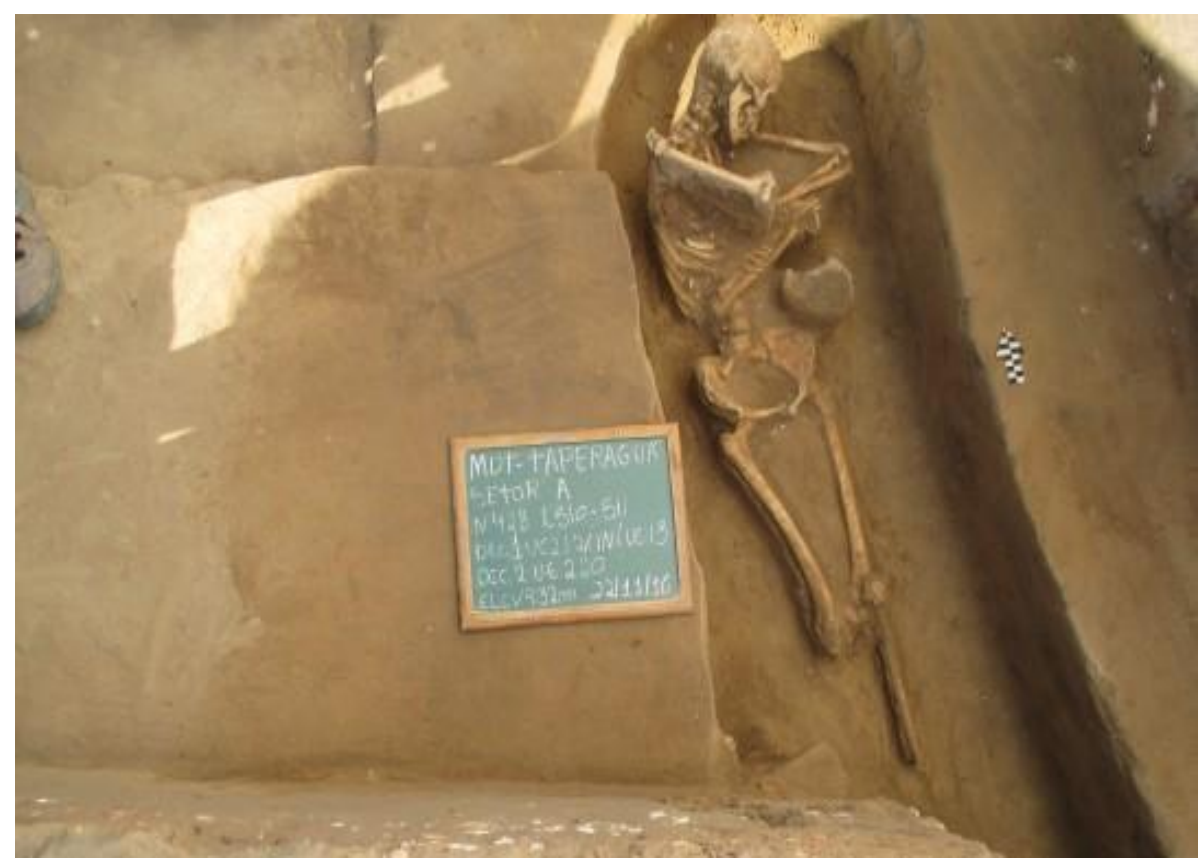

Figura 4: Sepultamento mostrando delimitação da cova. Fonte: Allen, 2017. 
Curar na Arqueologia: Preservação dos Remanescentes Ósseos Humanos do Largo da Igreja Nosso Senhor do Bonfim-Taperaguá, Marechal Deodoro, Alagoas

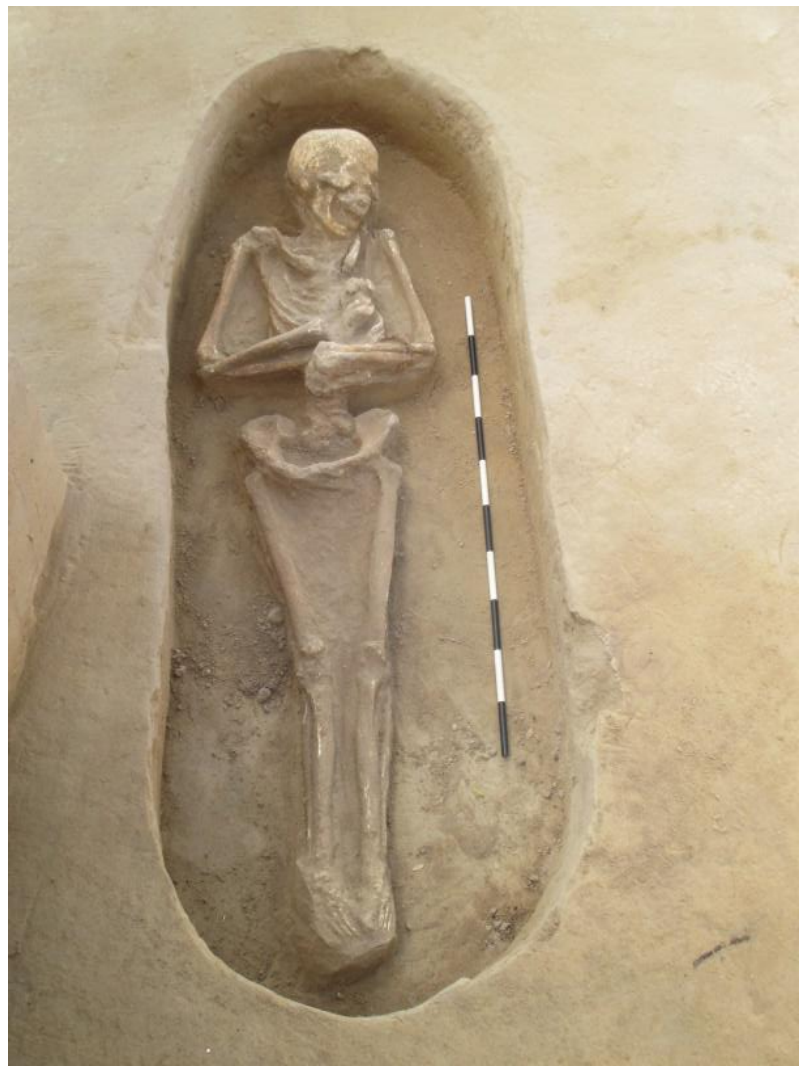

Figura 5: Indivíduo 1. Fonte: Allen, 2017.

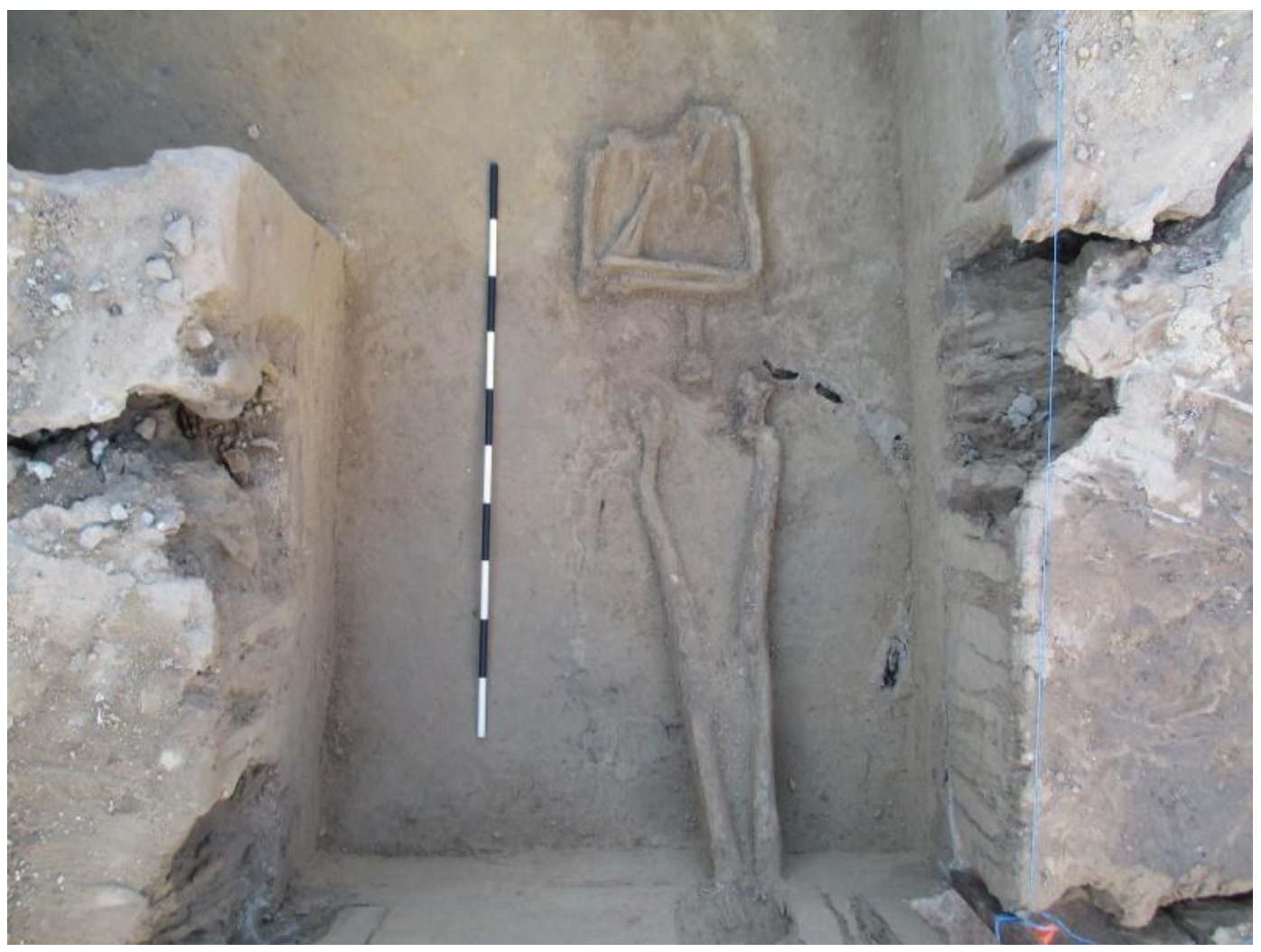

Figura 6: Indivíduo 3. Fonte: Allen, 2017. 
Segundo Allen, (2017:132), a técnica aplicada na escavação dos sepultamentos incluiu o uso de ferramentas voltadas à retirada cautelosa, tais como colheres Marshalltown, espátulas, luvas, máscaras etc. (Figura 7 e 8). Crânios e, por vezes, outros conjuntos de ossos, foram retirados com o sedimento para evitar danificação, optando para a consolidação em laboratório antes de analisados. Os materiais foram acondicionados ainda em campo para transporte.

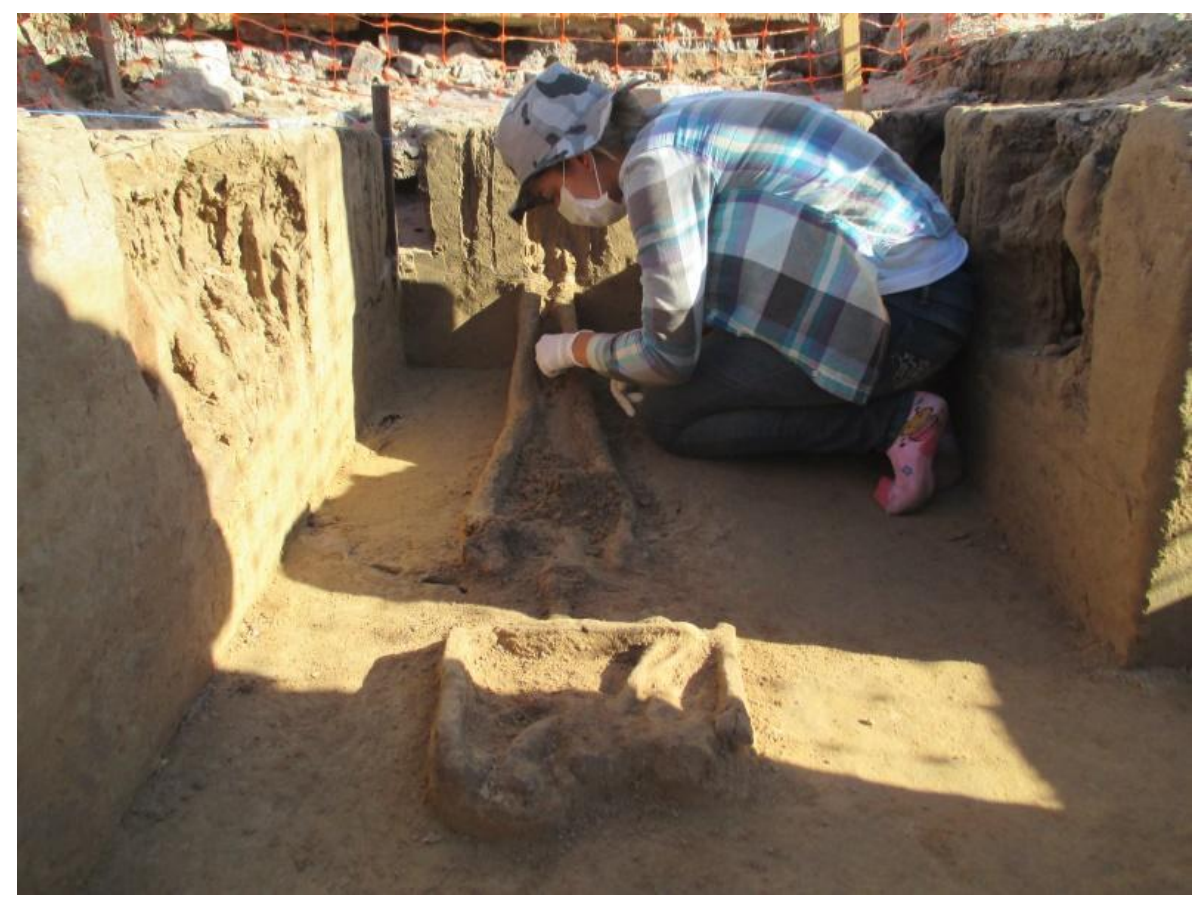

Figura 7: Limpeza dos indivíduos em campo utilizando luvas, máscaras e palitos de madeira. Fonte: Allen, 2017.

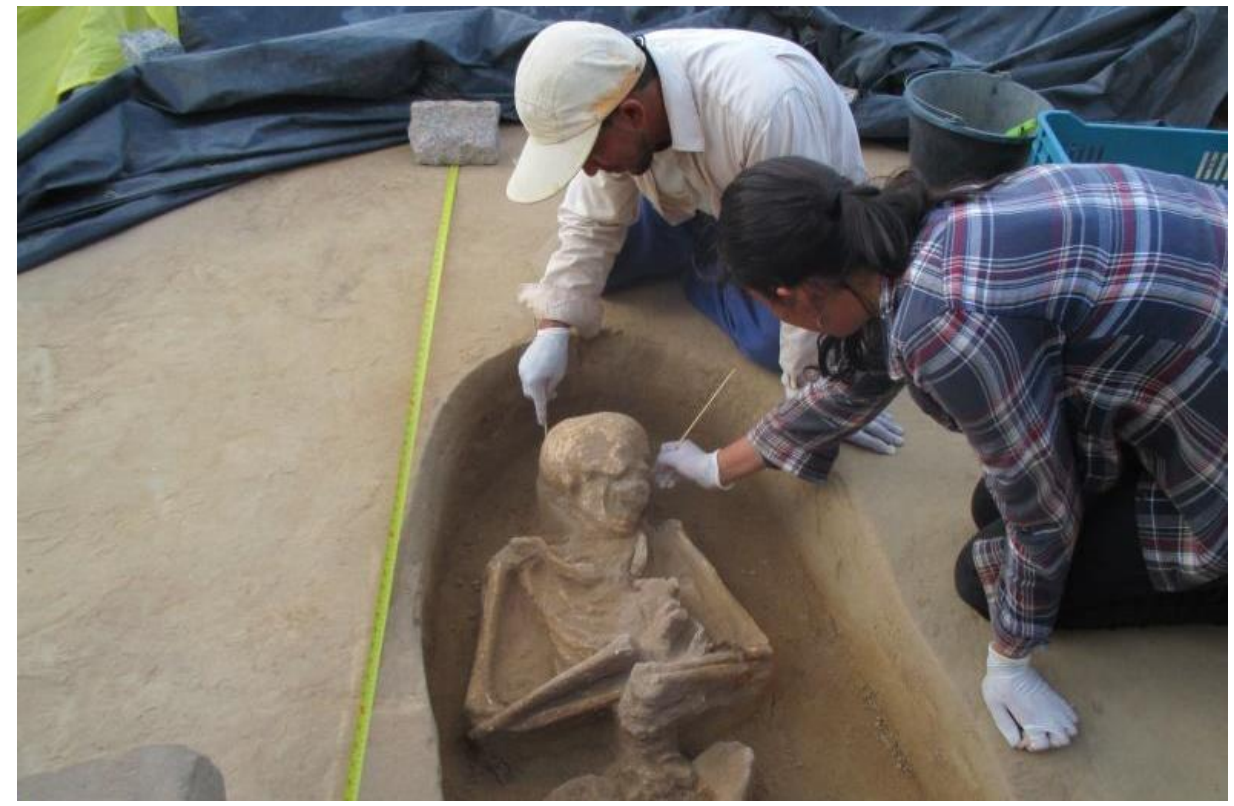

Figura 8: Limpeza dos indivíduos em campo utilizando luvas, máscaras e palitos de madeira. Fonte: Allen, 2017. 


\section{Conservação dos Remanescentes Ósseos do Largo da Igreja Nosso Senhor do Bonfim,} Taperaguá, Marechal Deodoro, Alagoas

O processo de coleta do material ósseo foi registrado através de formulários, fotografias, caderno de campo e das etiquetas identificando cada indivíduo, quadrícula, proveniência exata de cada material ósseo, entre outros. "O olhar no campo é fundamental para o registro de informações, especialmente em casos nos quais os remanescentes estão friáveis ou suficientemente comprometidos em sua integridade estrutural" (Carvalho, 2017:226).

Dessa forma, o problema maior com o material, foi a fragilidade de como se encontrava os ossos, ou seja, muito friável e com bioperturbação. Segundo Bezerra e Silva (2009:128), os remanescentes ósseos humanos e os artefatos sobre osso apresentam-se, quase sempre, desidratados, quebradiços ou friáveis, por já haver desaparecido a fração proteica do material.

Uma questão fundamental foi o que fazer para coletar o material sem danificá-lo ao ponto de perder sua morfologia óssea e de como esse material poderia ser preservado em laboratório? A proposta para isso foi a retirada do material foi em bloco ${ }^{4}$, dessa forma os ossos estariam salvos com sua "integridade", apesar de tamanha fragilidade. "A importância do trabalho de conservação é paralisar o processo de deterioração e salvaguardar o material arqueológico alongando sua vida nos museus ou depósitos, assegurando seu manuseio" (Berducon, 1990 apud Bezerra e Silva, 2009:126).

Para as coletas do material ósseo e necessário conhecimento do material em si, como vai ser coletado, entre outros. De acordo com Bezerra e Silva (2009:125), a descoberta de remanescentes físicos humanos em um sítio implicará na necessidade da presença de um técnico com experiência e conhecimentos básicos em curadoria de remanescentes ósseos, para interpretar a condição do achado, decidir sobre técnicas de retirada desse material do solo e como este deverá ser acondicionado, tanto em campo, como em laboratório, para posterior estudo.

Para Carvalho (2017:227), a escolha pelo resgate peça a peça ou pela retirada em bloco do todo ou de segmentos especiais, do uso ou não de consolidantes, entre outras ações, depende

\footnotetext{
${ }^{4}$ Sedimento envolto sobre os ossos.
} 
de uma complicada equação que envolve as condições de preservação dos ossos, os materiais, as condições técnicas, a equipe e o tempo disponíveis para cada ação.

Obviamente todo o processo de limpeza foi realizado em laboratório de forma cautelosa e, quando necessário, utilizando consolidantes para tardar o processo de deterioração dos ossos, conservando todas as informações possíveis, " [...] já que de pouco ou nada adianta a escavação se tal acervo não for submetido a rigorosos estudos para obtenção de reconstituições da história biossocial das populações" (Bezerra e Silva, 2009:125).

Para trabalho de curadoria dos remanescentes ósseos escavados na Igreja do Nosso Senhor do Bonfim, utilizou-se o conhecimento bioarqueológico, através de orientações de docentes especializados em material ósseo e conservação, assim como referências bibliográficas. Todo o trabalho para preparação da solução consolidante foi realizado de forma experimental com orientação da professora Neuvânia Ghetti ${ }^{5}$. As demais informações de como proceder com o material ósseo ficou a cargo da orientação do professor Sergio Monteiro. Após todo o processo de curadoria, os ossos estão sendo acompanhados por inspeções, a fim de controlar a continuidade da conservação.

\section{Metodologia para Conservação dos Remanescentes Ósseos do Largo da Igreja Nosso Senhor Do Bonfim, Taperaguá, Marechal Deodoro, Alagoas}

Segundo Carvalho (2017:229) alguns materiais, a despeito de todas as precauções, podem acumular umidade e nem sempre devem ser imediatamente manipulados, após a abertura de seus invólucros. Dessa forma, foi retirado o material ósseo de suas respectivas caixas de acondicionamento para um breve diagnóstico e, de acordo com o resultado, foram atribuídos procedimentos cabíveis para cada situação (Figura 9). "No caso de esqueletos fragmentados que precisam ser restaurados, recomenda-se a organização por região anatômica e lado, ou seja, organizar de forma separada os fragmentos de crânio, ossos longos, pés e mãos, costelas e os fragmentos não identificados" (Okumura, 2015:218).

Um desses procedimentos principais foi a consolidação do material ósseo, utilizando emulsões de solução de Acetato de Polivinila (PVA) mais água deionizada (Figuras 10 e 11). Não esquecendo que, para a aplicação dessa solução, é necessário que o osso esteja limpo,

\footnotetext{
${ }^{5}$ Coordenou o laboratório de arqueologia para conservação (LACOR) na UFPE.
} 
principalmente na superfície óssea que será aplicada. A dosagem para a aplicação desse material vai de acordo com a fragilidade dos ossos e que todas são solúveis em água. Cabe ressaltar que antes da aplicação do consolidante nos materiais ósseos humanos, fez-se testes em ossos de animais não arqueológicos provenientes do LABIFOR $^{6}$, do Departamento de Arqueologia da UFPE, e que se encontrava em estado de deterioração. O objetivo foi verificar como a solução de PVA reagiria ao material ósseo.

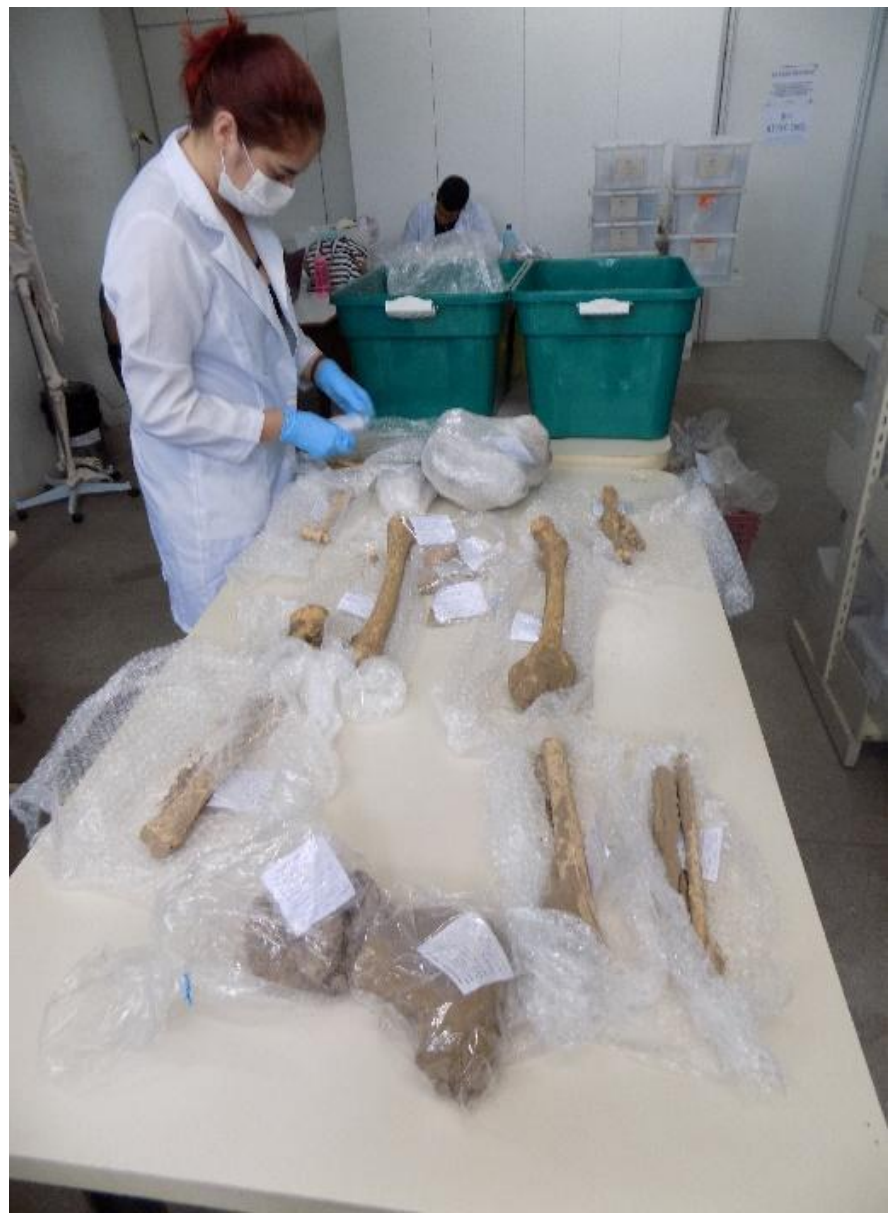

Figura 9: Material ósseo exposto para retirada da umidade e para um diagnóstico de como proceder com o processo de curadoria. Fonte: Neri, 2017.

Esse processo teve como principal objetivo evitar que o material ósseo se deteriore ainda mais, ou seja, Ihe conferi uma resistência mecânica maior. Já no caso de apenas consolidar os ossos sem retirá-lo do sedimento, há de se pensar que ficaram inertes a condições diferentes que serão expostos, caso venham a ser retirados ou se os ossos estiverem em um estado de deterioração muito crítico não seria ideal a retirada do sedimento em alguns casos.

\footnotetext{
${ }^{6}$ Laboratório de Arqueologia Biológica e Forense.
} 


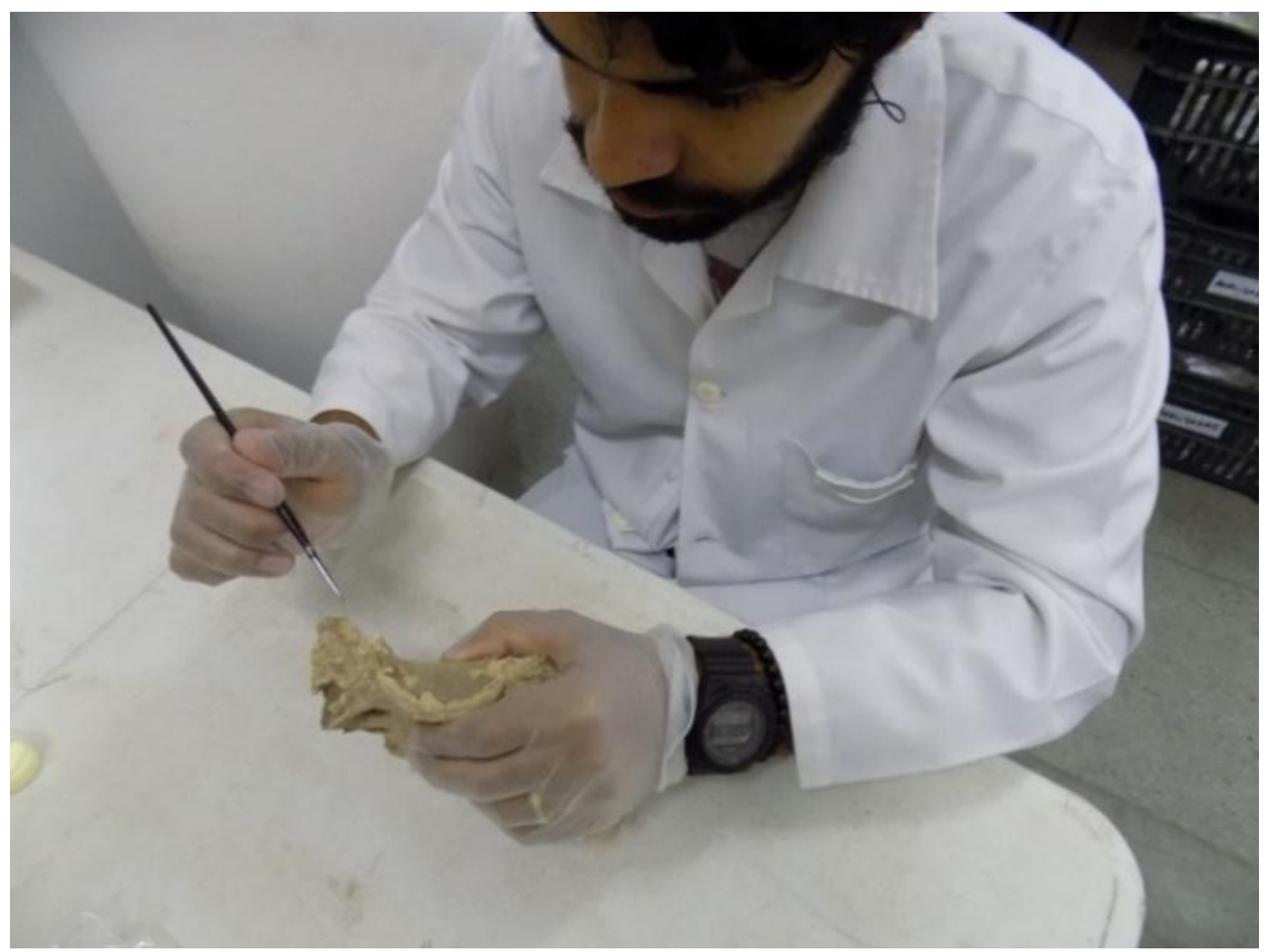

Figuras 10: Utilização do consolidante no material ósseo humano arqueológico. Fonte: Neri, 2017.

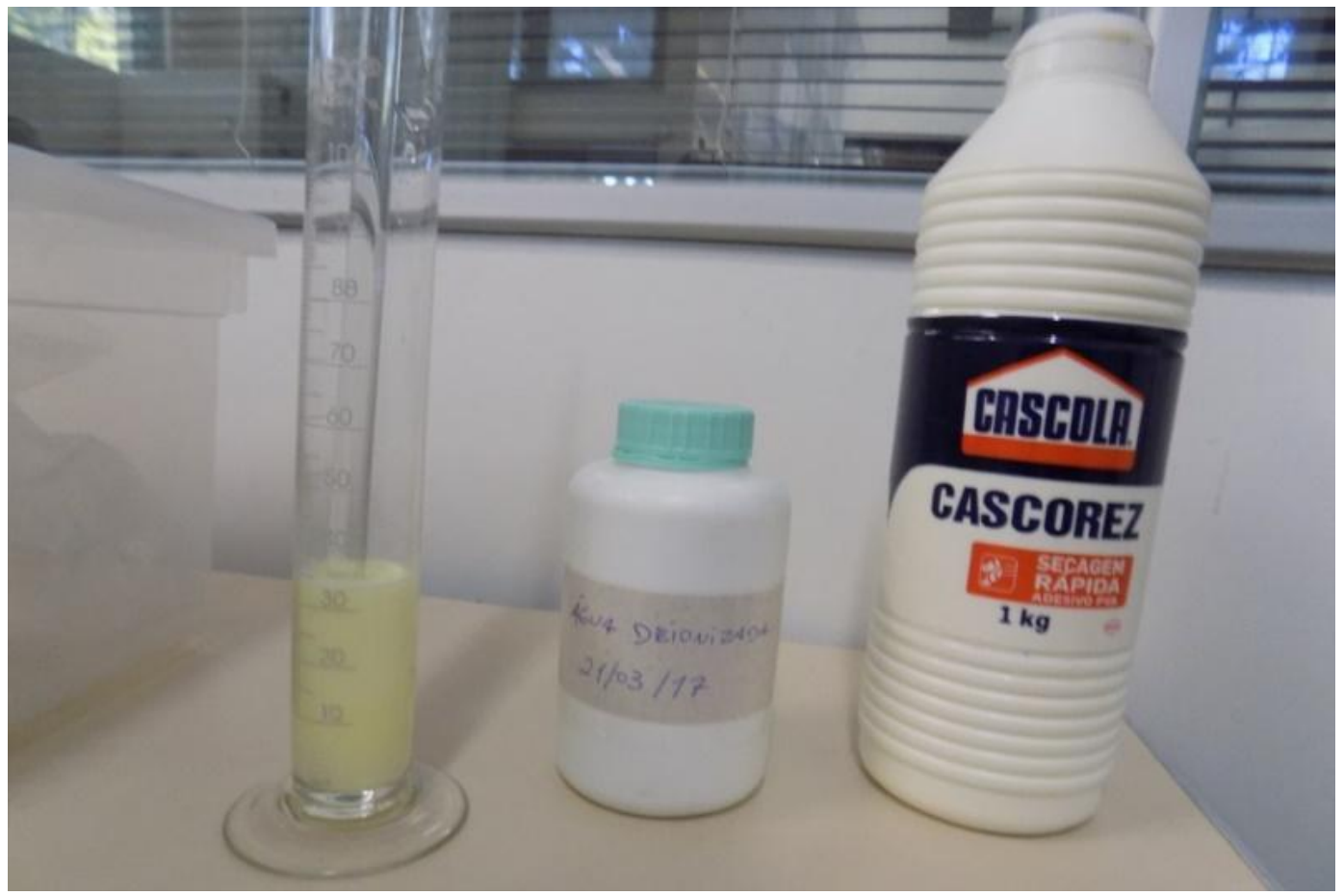

Figuras 10: Materiais utilizadas para fazer a solução consolidante. Fonte: Neri, 2017. 
A limpeza de materiais esqueletais, juntamente com o restauro e acondicionamento, são essenciais no contexto de uma coleção, pois a preservação de informações importantíssimas depende da boa realização dessas etapas (Okumura, 2015:217). Para o trabalho se utilizou algumas ferramentas como pinceis, luvas de látex sem amido, palitos (para a retirada do sedimento), máscaras, peneira e bandeja. Foi atribuído o processo mecânico de retirada a $\operatorname{seco}^{7}$ do sedimento ou qualquer outro tipo de depósito superficial que impossibilite a análise do material ósseo, não se esquecendo de trabalhar minuciosamente e com cuidado. Pinceis de sedas vegetais e sedas de animais, de dois tamanhos (14 e 8), que foram usados para a retirada do sedimento externamente e se possível internamente, todo esse trabalho foi realizado sobre uma bandeja que teve como objetivo recuperar e centralizar os fragmentos minúsculos que caírem (Figura 12).

Já os palitos tiveram como finalidade retirar o sedimento mais sólido do entorno do osso sem danificá-lo. As luvas sem amido ajudaram para não contaminação dos ossos, não prejudicando as análises futuras, principalmente as polínicas caso venham a ser feitas. "É importante saber que as luvas de látex, que devem ser usadas sempre, não devem conter pó, pois este é composto de amido, que provocará a contaminação nos materiais arqueológicos" (Bezerra e Silva, 2009: 130).

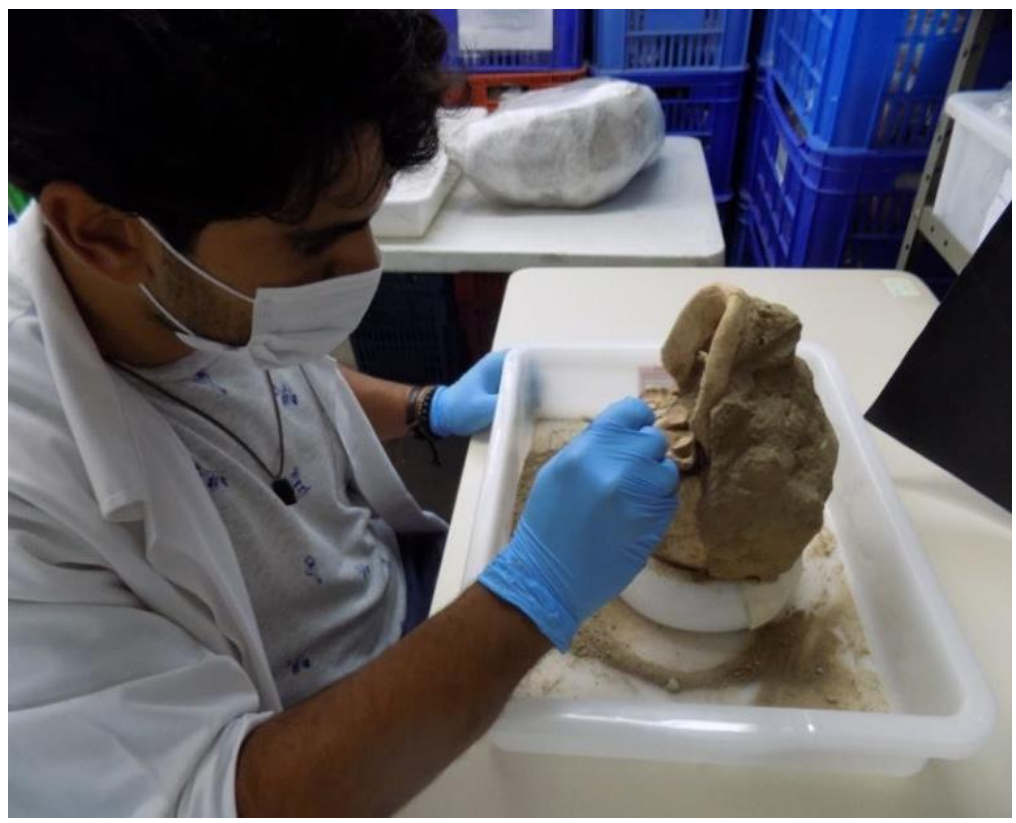

Figura 12: Limpeza cautelosa com palito de madeira, luvas sem amido, máscara e bandeja. Fonte: Neri, 2017.

\footnotetext{
${ }^{7}$ Sem a utilização de água deionizada para a limpeza.
} 
Ao terminar todo esse processo de limpeza, se fez o procedimento de análise dos indivíduos um por um, a fim de identificar qualquer informação que seja coerente para a pesquisa como sexo, patologia, ancestralidade, idade estimada, tamanho etc. Para fornecer o suporte necessário na identificação e comparação dos ossos, alguns manuais de anatomia e coleções de referência foram usados. Todo esse trabalho se fez registro, através de fotografias, relatórios e formulários que foram utilizados para preencher as informações de limpeza e análise de cada indivíduo.

Para o acondicionamento dos ossos, foram usados dois critérios de separação, fragilidade e tamanho (morfologia) - que teve o objetivo de guardar os materiais sem maiores danos. Segundo Bezerra e Silva (Op. Cit.), sempre ao acondicionar material ósseo, se deve ter certeza de que os sacos mais pesados sejam colocados no fundo.

Por fim, cada osso foi envolto em plástico bolha e guardado em sacos plásticos individualmente e, em seguida, colocados em caixas acolchoadas com plástico bolha, assim como os crânios em suas caixas individuais, também acolchoadas com o mesmo plástico. É necessário fazer acompanhamento desses materiais, para verificar como está se comportando o consolidante, assim como está a umidade, uma vez que os ossos estão em caixas. "No caso de materiais que tenham sofrido ataque biológico [como fungos], após a limpeza adequada, sugere-se um monitoramento periódico do estado de preservação dos mesmos[...]" (Okumura, 2015:218).

\section{Resultado}

Os resultados foram bastante satisfatórios, dos 6 indivíduos submetidos aos processos de curadoria, $90 \%$ tiveram as suas integridades e morfologia óssea restauradas. Os $10 \%$ resultaram para ossos com as suas integridades restauradas, porém a morfologia não. Alguns ossos tiveram a sua reconstituição. Dessa forma, o objetivo foi assegurar informações mais precisas sobre o material ósseo. Para os ossos consolidados foi criado um formulário ilustrativo mostrando quais dos ossos foram consolidados, permitindo o controle de cada material.

Através de orientação do pesquisador e docente da UFPE, Sergio Monteiro, foi proposto para alguns crânios permanecerem com o sedimento interno, devido à fragilidade como se encontravam, ou seja, em se retirando o sedimento, ocasionaria a quebra literalmente do 
Curar na Arqueologia: Preservação dos Remanescentes Ósseos Humanos do Largo da Igreja Nosso Senhor do Bonfim-Taperaguá, Marechal Deodoro, Alagoas

crânio. Foram coletados sedimentos dos ossos longos, das pelves e dos tórax, a fim de identificar traços tafonômicos, possíveis parasitas, dieta alimentar, entre outros.

Materiais como uma lasca de sílex, contas de colar e uma pulseira de ferro que estava entre o antebraço esquerdo do Indivíduo $3^{8}$ foram encontrados durante a limpeza dos indivíduos. Todo esse material foi registrado por meio de relatórios, formulários e fotografias. Cabe ressaltar que esses materiais precisam ser analisados futuramente, atribuindo respostas do que pode ser, e qual a relação com os indivíduos.

Seguem, nas próximas páginas, ilustrações dos processos discutidos no texto, antes e depois da curadoria. Detalhe para o crânio do Indivíduo 3 (Figura 13 e 14).
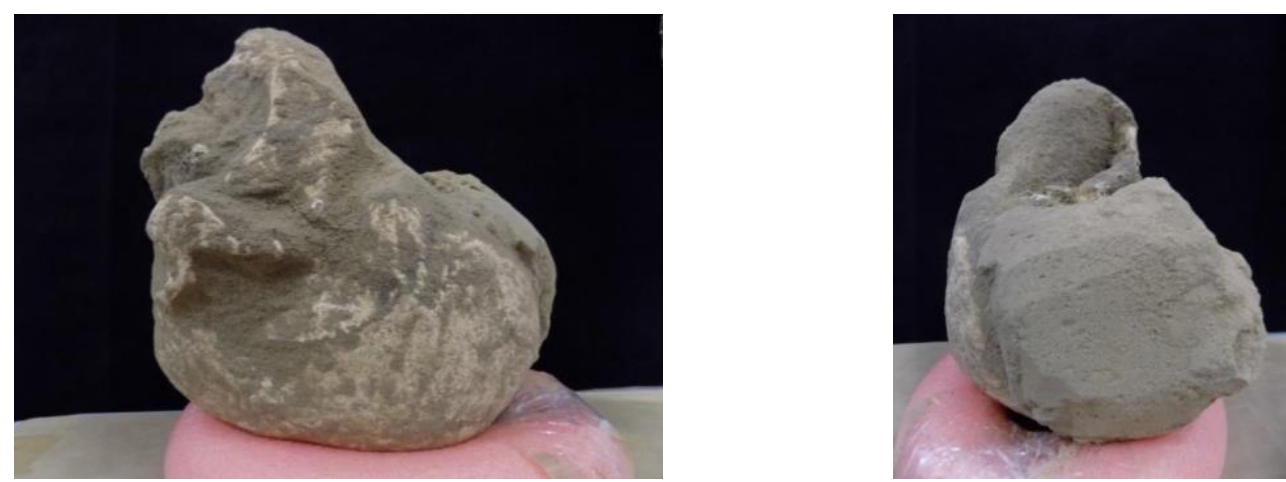

Figura 13: Crânio vista lateral direita e vista inferior com sedimento. Fonte: Neri, 2017.
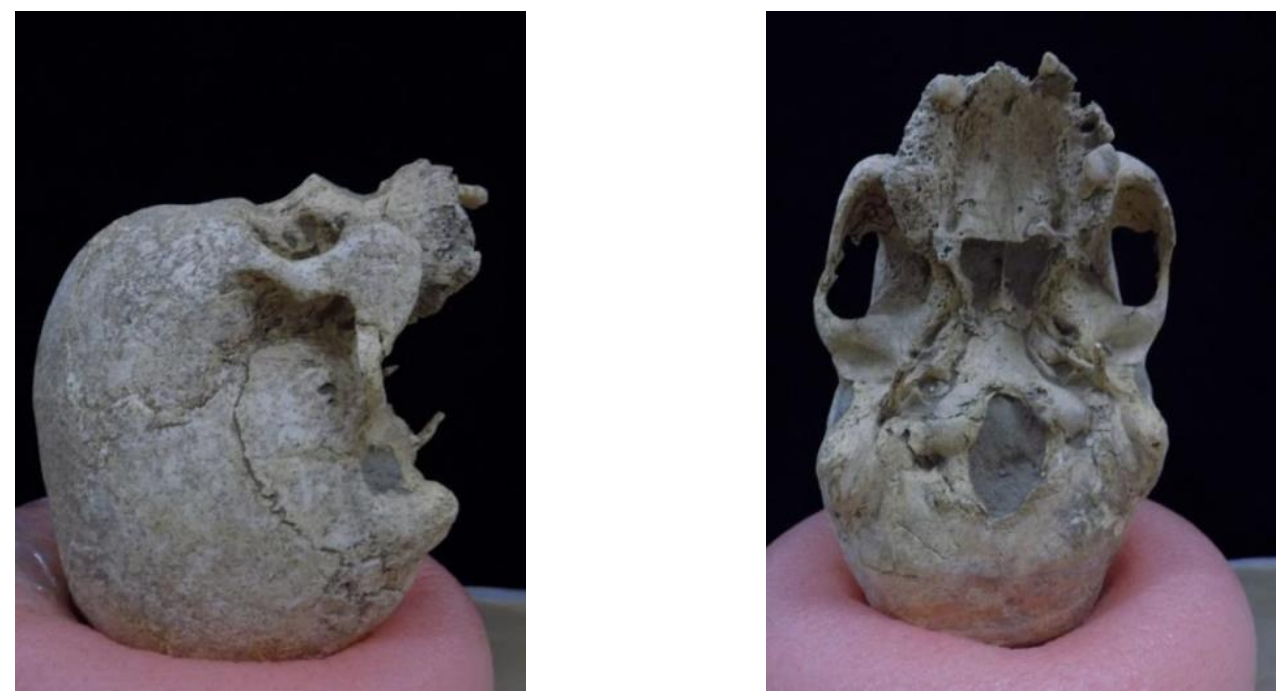

Figura 14: Vista lateral direita e vista inferior sem o sedimento. Fonte: Neri, 2017.

${ }^{8}$ Ver (Ferreira, 2018). 
Ilustração de reconstituição dos resultados para ossos da clavícula direita e falanges da mão (Figuras 15 e 16).
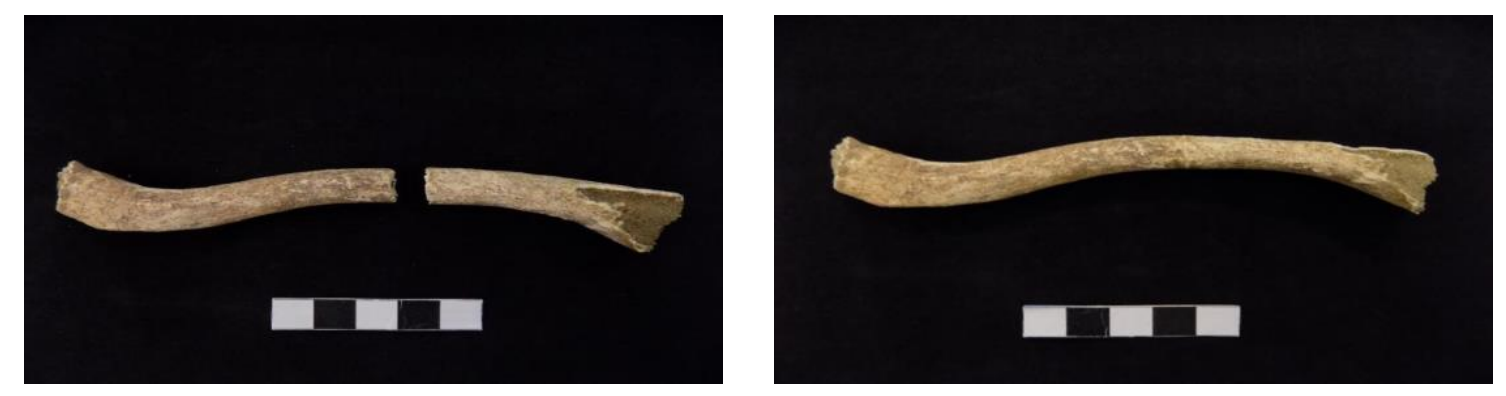

Figura 15: Reconstituição da clavícula. Fonte: Neri, 2017.
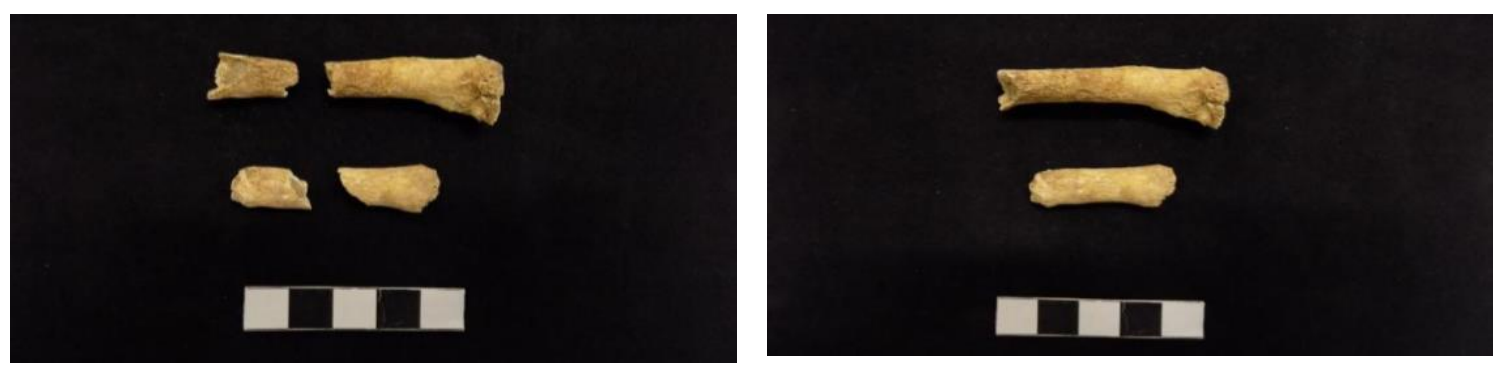

Figura 16: Reconstituição da falange da mão. Fonte: Neri, 2017.

Por fim uma ilustração mostrando controle de ossos consolidados e não consolidados para futuras análises (Figura 17). Para todos os indivíduos foi utilizado o mesmo modo para o processo de consolidação.

Todos esses resultados proporcionaram uma resistência ainda maior aos materiais ósseos, tendo em vista a fragilidade que se encontravam. Assim como propôs uma forma válida de consolidação desses materiais utilizando o PVA Neutro, gerando assim um processo mais acessível, simples e de fácil manuseio. 


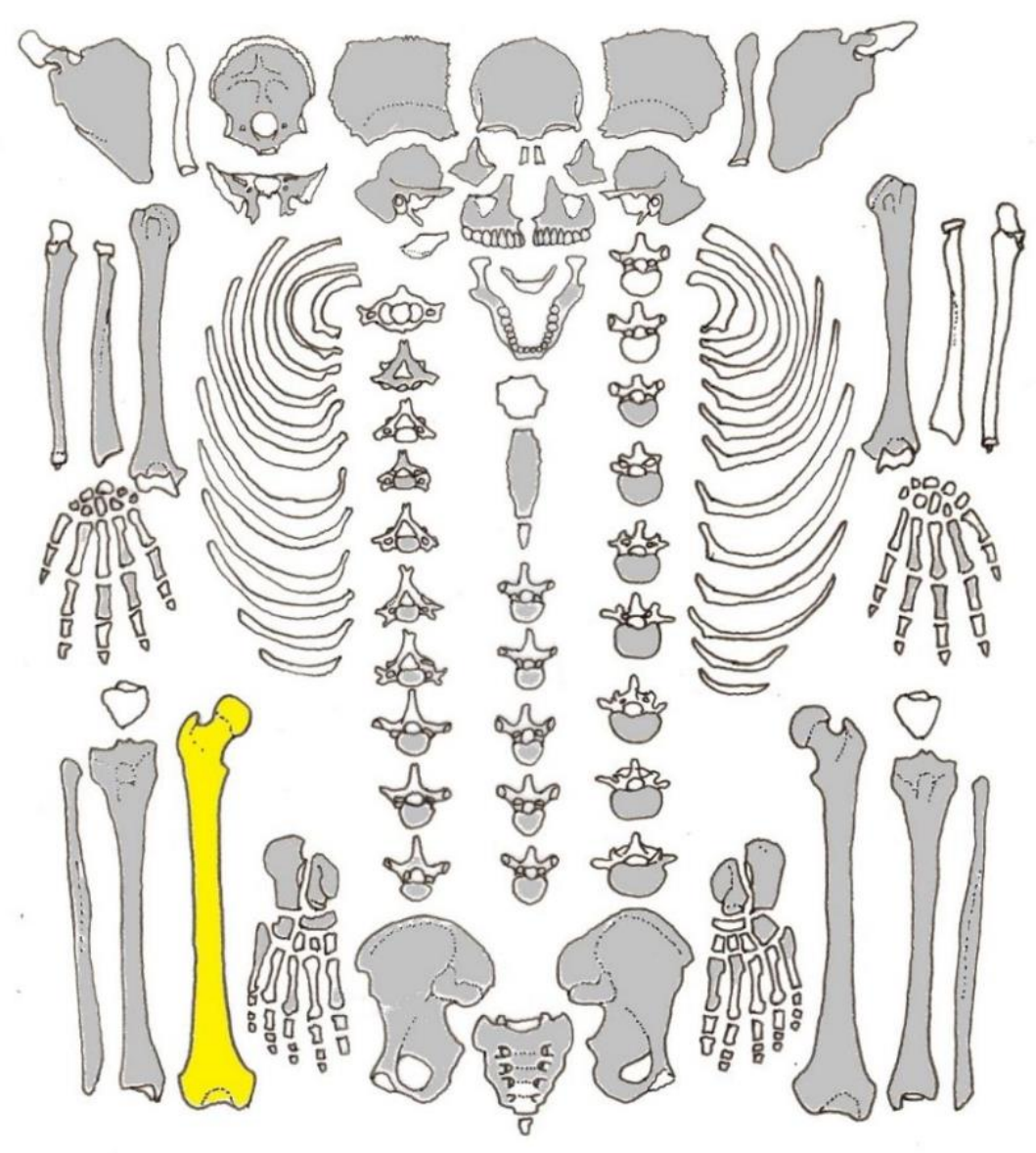

Figura 17: Diagrama de ossos consolidados e não consolidados individuo 3. Os ossos pintados em cinza correspondem aos consolidados, já os que estão em amarelo correspondem aos não consolidados. Fonte: Neri, 2017.

\section{Conclusão}

Respeitar o ser e o sagrado é importante, uma vez que se manipula o morto, o seu espaço (a igreja), que remete a uma associação desses indivíduos ao mais perto do divino, bem como ao saber comum da população que esteve presente durante a escavação, visitando e compartilhando as experiências em caráter espiritual ou apenas por curiosidade. A partir dessas reflexões pede-se espaço para um trabalho árduo e cauteloso que requer atenção total e conhecimento prévio sobre ossos. Dessa forma a curadoria do remanescentes ósseo humanos da Igreja Nosso Senhor do Bonfim, Marechal Deodoro, Alagoas se fez presente nesse trabalho, concluído com êxito e extremo respeito, partindo da importância do curador para com o material ósseo tornando-o crucial para uma boa longevidade, assim como para um bom controle em laboratório. "Parece ser clara a enorme importância da figura do curador para o 
bom gerenciamento de coleções de remanescentes humanos, sem o qual não é possível explorar de forma satisfatória o potencial das mesmas na interação com pesquisadores e com o público geral" (Okumura, 2015:220).

Segundo Silva, Ghetti e Santos (2016:427) os esforços realizados para a guarda, cura e conservações de coleções de esqueletos humanos de precedência arqueológica são extremamente benéficos para o desenvolvimento do conhecimento científico. Dessa forma os resultados desse processo tem recíprocos esforços, principalmente pelo retorno de trabalhos acadêmicos gerados a partir dessa curadoria e que ainda estão por vir, assim como levantar debates a cerca desses indivíduos, quem são e de onde vieram?

\section{Agradecimentos}

A professora Neuvânia C. Ghetti pelas orientações de como criar a solução consolidante e nas dúvidas de conservação de material orgânico, assim como ao professor Sergio S. F. M. Silva pelas orientações de como proceder com o processo de curadoria do material ósseo de uma forma geral.

\section{Referências}

ALLEN, J. S.; POLUHA, B.; PORSANI, L. 2017. Geofísica Arqueológica no Ambiente da Arqueologia Urbana. Revista de Arqueologia v:30, n.1, p. 235-254.

ALLEN, S. J. 2017. Pesquisa Arqueológica no Largo da Igreja Nosso Senhor do Bonfim, Taperaguá, Marechal. Deodoro, Alagoas. Maceió.

BEZERRA, I. e SILVA, H. P. 2009. Tirando do Pó: Uma introdução Metodológica sobre o tratamento de Remanescentes ósseos humanos de Origem Arqueológica. Revista de Arqueologia, v.22, n.2, (agodez.2009): 121- 135.

CARVALHO, C. R. 2017. Preservação de Remanescentes Biológicos Humanos de Proveniência Arqueológica: mais algumas questões. Preservação do Patrimônio Arqueológico: desafios e estudos de caso.

DIAS, P. M. 2013. Novos Métodos Curatoriais Aplicados Aos Materiais Arqueológicos: da intervenção ao acervo. Revista LEPA - Textos de Arqueologia e Patrimônio, Santa Maria.

LESSA, A. 2017. Do Pó Viemos E Ao Pó Retornaremos: Pontuando Reflexões Sobre Preservação De Remanescentes Esqueléticos Arqueológicos Humanos. Preservação do Patrimônio Arqueológico: desafios e estudos de caso, p. 233-252. 
Curar na Arqueologia: Preservação dos Remanescentes Ósseos Humanos do Largo da Igreja Nosso Senhor do Bonfim-Taperaguá, Marechal Deodoro, Alagoas

OKUMURA, M. 2015. Curadoria De Remanescentes Humanos: Práticas E Experiências Na Coleção Duckworth (Universidade De Cambridge, Reino Unido). Revista Tecnologia e Ambiente, Dossiê IX Reunião da Sociedade de Arqueologia Brasileira / Regional Sul. , v. 21, n. 1, p. 211-222.

SILVA, M. S. F. S.; GHETTI, C. N.; SANTOS, B. R. C. 2016. Ensaio Sobre Preservação de Materiais Arqueológicos De Natureza Orgânica Da Retec-Arq da UFPE: Remanescentes Ósseos Humanos. Museu de Astronomia e Ciências Afins-MAST, Rio de Janeiro. 